\title{
Reform and Practice of University Computer Basic Course on Evaluation System
}

\author{
Xin Sui
}

\section{College of Humanities \& Sciences of Northeast Normal University, Chang Chun, 130117, China}

Keywords: University computer; Compulsory course; Evaluation system; Teaching reform; Talent training mode

\begin{abstract}
The university computer foundation is a public compulsory course in Colleges and universities. With the rapid development of information technology, the continuous improvement of teaching ideas and with the constant renewal of teaching methods, traditional teaching methods can not meet the needs of nowadays university education. In order to further improve the quality of undergraduate education, improve the quality of talent cultivation, college basic computer course teaching reform has been crunch time. This paper mainly discusses the University Computer Foundation Course in the evaluation system etc are existing problems, elaborated with emphasis in the new personnel training mode of university computer basis curriculum evaluation system reform and implementation of. Compared the reform before and after the students' learning attitude, effect, performance, the evaluation system of college computer the basic course of reform, through the reform of the evaluation system of computer basic course in University, the students' learning ability is more effective to promote the ability of students to actively adapt to the community, and is conducive to the new model of personnel training.
\end{abstract}

\section{Introduction}

Most of the teaching quality evaluation model generally adopts the comparative economics by means of examination, the pure scores as criteria for evaluation of teaching effect. The traditional evaluation models too much emphasis on the results, only without attaches' great importance to the process.

"Fundamentals of computer" is granted by the ministry of education of a public required course for college freshman [1-2]. "Fundamentals of computer" practical courses, the computer technology rapid development, computer system software and application software are colorful, updated quickly, the application of new technology with each passing day. This new characteristics have decided to university computer foundation course in the teaching content should be constantly updated; can evaluation methods should be reasonable and effective to adapt to the development of new technology. [3-4]

\section{Teaching Evaluation}

Test evaluation system should not only focus on the student to the knowledge, more should pay attention to students throughout the learning process, emotion and attitude towards learning, such as an emphasis to cultivate the students' interest in learning, learning habit and the ability of autonomous learning. After the reform of evaluation system of the learning process of students at ordinary times as an important index of assessment, the classroom computer experiment, the performance of the test, the mid-term test and application of information technology in various professional disciplines study ability to solve problems, and comprehensive evaluation for students. [5-7]

Teaching evaluation is a basic link in the process of teaching, the results of the evaluation has an important influence on students' learning attitude. Respond to students' learning process and learning into a comprehensive objective evaluation. [8-9]

Most university computer foundation course evaluation methods at present is the final summative evaluation is given priority to. Teacher is the student's final exam achievement to assess 
students. The traditional way of evaluation in the final examination results as the standard of judgment, too much emphasis on test scores. Students in order to cope with the exam, only focus on knowledge related to exam, has nothing to do with the examination of knowledge points, even if is very important, the students may not spend too much time and energy to study, review's interest of learning. The traditional evaluation method ignores the subjectivity of students in the learning process, initiative and creativity, not well stimulate students' learning enthusiasm and persistence, and it also does not favor the university computer foundation course teaching methods and content of the reform. [10-12]

\section{The Evaluation of Teaching Reform}

According to the dean of the spirit of the examination reform, considering the arts university computer class is given priority to with operation, case teaching throughout. Given the request for the test does not conform to the ministry of education about "for the purpose of application," focusing on the practice requirement, and the arts not to participate in grade examination, I think the examination reform is imperative.

According to the university computer teaching requirements (2011 edition) for the purpose of application, focusing on practice, focus on the training of information literacy ". And our student exam comparative economics, is less; Less theory test, investigation, emphasize the course at the end of the examination, the neglect of the actual situation in the process of teaching, 2015-2016 school year second semester public computer actuarial-oriented an open-book exam on the university computer teaching reform.

Assessment Method. An open-book exam object of teaching reform is the school art class freshman level 2015, before the actuarial-oriented) against a level 2014 department of radio, film and four classes (both for small class) tried an open-book exam, and as a pilot. Performance appraisal is that the final judgment result $=$ grades + the mid-term test, final computer test, and the specific scores as shown in table 1, all tests are in the form of an open-book exam. Grades is primarily for students at ordinary times learning state, learning examination; Midterm and final practice on computer test is mainly to investigate the students' ability of practical operation and application.

Student Performance. Classroom discipline than last semester obviously improved; Students pay more attention to the learning of this course, obviously improve the learning enthusiasm and learning enthusiasm. Class most of the students can listen earnestly, can according to the requirements of the teacher for computer operation practice seriously. If you have not do topic, most of the students can take the initiative to ask the teacher, the students feel really learned knowledge, improve the ability of practical operation. This assessment method and strong to mobilize the initiative of students, has received the good teaching effect.

In communication with some students learned that most of the students think by comparative economics into an open-book exam, not only is the change of form, and is the change of the content. An open-book exam pay more attention to the usual assessment, if performance is not good at ordinary times, can't be the last final exam alone to pass the exam. Most of the students realized that if you want to pass the exam, obtain good result, must follow the requirements of the teacher, for each class, finish every homework carefully and seriously every computer test. Only in this way can step by step, the whole semester teaching content entirely, smoothly pass the exam. The process of learning throughout the semester, most students can keep up with the teacher's teaching progress, can take the initiative to think, to explore the method to solve the problem, make monotonous operation becomes vivid, lively, firmly grasped the theory basis for knowledge, and truly improve the practical ability. Students are more agree with an open-book exam this assessment method.

The Teachers' Main Job. Throughout the semester teaching process, teachers in the basic teaching task, on the basis of strict examination for students at ordinary times, carefully record students' classroom performance, give students grades. Teacher carefully examines students hand in written work and electronic homework every time. For each test, the teacher will be divided into 4 or 8 group classes, passed close to the ease of different topic, classroom teachers serious test, test 
each student's actual master degree and real results. Compared to other classes, the open-book exam pilot increases the workload of teachers.

\section{The Effect of the Reform}

Through an open-book exam pilot, greatly mobilized the enthusiasm of students learning, more truly and objectively evaluate the students' study effect, avoid the students usually don't work, "cramming" to test the shock phenomenon. Implements the comprehensive assessment theory and practical operation ability, obviously improves the teaching quality.

\section{Conclusion}

Arts an open-book exam to a certain extent, ease the burden of students' test, to overcome the traditional examination way heavy theory, light practice, heavy memory, the theory of light. Greatly improving the student's study enthusiasm, cultivating the students' ability of autonomous learning, to make the students really aware of the importance of the accumulation of at ordinary times, has obtained the good teaching effect. This assessment method avoids the students blindly in pursuit of high scores, before the final exam blind rote learning; pay more attention to the test in the process of learning. Through this assessment method, can better improve the students' learning ability, practical ability, make students learn knowledge, skills, to better promote the students' ability to actively adapt to the society, more conducive to the new personnel training mode. An open-book exam to avoid the commando-style studying before the final exam, the students to profoundly understand an open-book exam is not the simple books, to solve the problem focuses on the practical application ability, a greater challenge.

In computer teaching reform in university, always adhere to the university computer foundation teaching goal and the new type of composite talent training goal, the content of the university computer foundation teaching with interdisciplinary professional to join each other phase permeability, university computer foundation teaching practice the principle of combining the basic and application, further reform of college basic computer course system, reforming teaching contents, reform the examination evaluation system, writing to keep pace with The Times is suitable for the practical teaching, the school students constantly optimize teachers, realize the goal of the reform of the university computer foundation course. [13-14]

\section{Acknowledgements}

The Ministry of education reform project "The Construction and Research of the Teaching Materials of the Liberal Arts University Computer Class" project number: 2014-A100.The education of Jilin province "in 13th Five-Year" plan 2016 annual key project (Project No. ZD16071). Jilin Provincial Higher Education Association 2016 annual higher education research subject "based on SPOC" Access database technology and application "mixed teaching mode" (subject number: JGJX2016B27) results. 2016 Jilin higher education reform research project "based on MOOC+SPOC flipped classroom teaching mode" research results.

\section{References}

[1] Xiong Lili. Research on classroom teaching evaluation of university computer basic course [D]. Changchun Teachers College, 2010.

[2] Zhu Libo. Development of student evaluation in the university "computer culture foundation" in the practice of [D]. Inner Mongolia Normal University, 2007.

[3] Cheng Ni. Construction of procedural evaluation scheme in computer basic teaching of university [J]. Journal of Yuncheng University, 2014.

[4] Xu Weike. Thinking on the construction of university computer curriculum evaluation system 
[J]. Education and Teaching Forum, 2011.

[5] Qi Jian. University computer basic education model and learning effect evaluation [J]. China Adult Education, 2009.

[6] Li Yingfang. "University computer foundation" teaching evaluation system [J]. New West (second half), 2009.

[7] Zhang Zimin, Fan Yanying. Fuzzy Comprehensive Evaluation of Computer Experiment Teaching Quality in University [J] Journal of Hezhou University, 2012.

[8] Liu Li, Zhang Xiaohui. University computer teaching material evaluation system [J]. Computer Education, 2008.

[9] Yang Gui. Teaching design of "computer culture basic course" based on project learning [J]. Inner Mongolia Normal University, 2007.

[10]Liang Tao. Application of formative assessment in computer basic teaching in universities [J]. Biotechnology World, 2013.

[11] Chen Hai, Ni Yuhua. Research and implementation of university computer based multi learning evaluation system [J]. Computer Education, 2008.

[12] Liao Yixing, Jin Qin, Mao Weiying. Discussion on the formation evaluation of computer basic teaching in university [J]. Fujian Computer, 2011.

[13]Zhang Xin. How to correct the teaching of "university computer foundation" through formative evaluation [J]. Journal of Jilin Province Education College (Science Edition), 2009.

[14]Liao Ruihua, Zhang Yanli, Liu Lin, Hu Ying. Based on the cultivation of independent innovation ability of university computer basic course teaching methods and evaluation methods reform [J]. China 's Off - Campus Education, 2009. 